\title{
Black Women and the Media in Britain
}

\begin{abstract}
This chapter outlines media developments and key matters concerning the on-screen depiction of Black women in Britain in recent decades. It draws on material accessed at the Black Cultural Archives (BCA) in Brixton, London and the Spare Rib digital archive at the British Library. This chapter discusses self-representing and organising in relation to Black women and the media. The discussion explores the politics of representation in connection with superficiality, conceptualisations of Black women's media experiences and television representations, as well as the influence of variations regarding regionality and rurality. This chapter emphasises that due to the geo-culturally and socio-politically specific setting of Britain - and its consititutive nations-work focused on the lives of Black women ( $t$ )here demands a critical lens that is sensitive to this context's various characteristics.
\end{abstract}

Keywords Activism · Black archives - Black women · Britain · Representation · Television

Here are Black women writing, unapologetically and with no holds barred, to, about, and for other Black women, using our own words, in a way that has not often been attempted before. (Melba Wilson 1982, p. 31)

F. Sobande, The Digital Lives of Black Women in Britain, Palgrave Studies in (Re)Presenting Gender, https://doi.org/10.1007/978-3-030-46679-4_2 
Published by the European Parliament in 1995, a European Women's Lobby report on the experiences of Black and migrant women in Europe noted the persistence of racism and far-right politics across the continent-paired with the ambivalence of governments that bore witness to this injustice. More than two decades later, little has changed. Black women in Europe continue to face insidious institutional anti-Black racism and interrelated oppression that can severely impact their health (Cole 2018; Emejulu and Sobande 2019; Walcott 2020). Today, Black women in Britain deal with the force of Euroscepticism that is often steeped in nationalistic and racist concepts of citizenship and Britishness, as well as the effects of backlash against neoliberal notions of multiculturalism, which the scholarship of political sociologist Akwugo Emejulu (2016) addresses. In sum, 'our right to be here is questioned almost daily by politicians and the media' (Bryan et al. 2018, p. 3).

Since its European Union (EU) referendum outcome in 2016, Britain's planned and eventual exit (Brexit) from the EU on 31 January 2020, has been linked to increasing racist hate crimes (Benson and Lewis 2019). Although such a political climate undoubtedly impacts Black women in Britain, it is crucial to acknowledge that these same women have experienced and documented discrimination at the nexus of anti-Black racism, sexism, classism, xenophobia, and other interlocking relations of power, long before Brexit (Bassel and Emejulu 2017; Bryan et al. 1985; Lewis 1993; Ngcobo 1987; Palmer 2011; Sulter 1985; the Brixton Black Women's Group and the Organisation for Women of African and Asian Descent 2017; Young 2000).

It is important to comprehend the intersecting nature of oppressions as 'social inequality is rarely caused by a single factor' (Hill Collins and Bilge 2016, p. 26). Efforts to understand the contemporary lives of Black women in Britain, including their digital encounters, require recognition of experiences of intersecting oppressions, as well as political organising and active production and critique of media and cultural spheres in past decades. Considering connected issues involves unpacking key concepts, theories, and perspectives that have played a central role in Black women's scholarly, literary, creative, grassroots, and everyday meditations on their lives and media experiences - then and now.

In turn, I draw on tenets of Black feminism which can be understood as being 'both a theory and a politics of affirmation and liberation' (Emejulu and Sobande 2019, p. 3) -based on the lives of Black women of African 
descent. I am also spurred on by the impetus of the anti-racist scholarship of Azeezat Johnson et al. (2018) which is 'about taking stock and bearing witness to the racial conditions in which we find ourselves' (p. 2). Before chapter three's stronger focus on the contemporary experiences of Black women in Britain, this chapter draws particularly on archival material and pre-existing written accounts. Discussion in the following sections of this chapter acknowledges that due to the geo-culturally and socio-politically specific context of Britain and its constitutive nations, work focused on the lives of Black women ( $t$ )here demands a critical lens that is sensitive to the characteristics of this setting (Bryan et al. 1985; Linton and Walcott 2018; Media Diversified 2016; Nassy Brown 1998; Obasi 2019; Omonira-Oyekanmi 2010; Palmer 2011; Perry 2016; Sims and Njaka 2019; Twine 2004, 2010).

\section{SElf-Representing AND Organising Around Black Women and THE Media}

As a rare national heritage centre which is committed to archiving and celebrating African and Caribbean histories, the Black Cultural Archives (BCA) in Brixton, is an invaluable source of information concerning decades of Black life in Britain. BCA is a space which contains writing, images and materials that symbolise how Black people have strived to record their histories, while speaking for and representing themselves in a context-Britain-located within an unshakeable ongoing colonial legacy (Gilroy 1987; Lewis 1993, 2000; Otele 2017, 2019; Owusu 2018; Perry 2016).

It is important to recognise that archives exist in many forms, including non-tangible and living ones (Hall 2001; Larasi 2019). Although for now, BCA is the only national heritage centre in Britain dedicated to archiving the history and contemporary experiences of Black people ( $t$ )here, myriad personal, digital, collectively gathered, lived, and privately kept Black archives exist in Britain. Therefore, whenever accessing material at BCA, I do so with an awareness of how absences in an archive do not equate to the non-existence of experiences, ephemera, documents, materials, thoughts, creative works, images, conversations, stories, and memories that are not present in that specific space (Sharpe 2016).

I write this only days after recent news regarding the financial difficulties that BCA faces. It is a centre that the government presently-in 
October 2018-does not fund, and in any case government funding could constrain the agency and politics of Black people involved in its direction. The collective, creative, and cultural pursuits of Black people in Britainparticularly Black women from working-class backgrounds-have often lacked substantial funding and institutional backing. In addition, due to pervasive 'neoliberal brand culture' (Banet-Weiser 2018, p. 13), such work is always at risk of being compromised and co-opted, including as a result of structurally white institutions becoming financially involved. Hence, decades of self-publication, self-representation, and community organising among Black women in Britain, which is now shaped by 'online content creation that enables the expression of political and social issues in dialogic and powerful ways, challenging the dominance of discussions led by traditional news outlets and gatekeepers' (Sobande 2019a, p. 152).

The vital scholarship and work of Black women such as historian Jade Bentil (forthcoming, 2021) provide insightful writing and research regarding Black women's experiences and resistance in Britain, especially during the late 1940s to late 1980s (Akpan 2019). The crucial collective-building activities of Black women in Britain include the formation of the Brixton Black Women's Group (BBWG) in 1973 (Lewis and Hemmings 2019) which campaigned and challenged structural inequalities concerning the lives of Black women, ranging from reproductive rights and labour experiences, to the provision of healthcare and education. The slightly later founding of the Organisation of Women of African and Asian Descent (OWAAD) in 1978 also reflects how Black women in Britain have worked to tackle systemic interconnected oppression and strive for societal change. In the words of Melba Wilson (1982), who has worked extensively across the areas of public policy, health, and social welfare, 'Black women themselves are the ones who should and will make the rules and set the standards against which they are to be judged' (p. 31).

As media and cultural industries scholars such as David Hesmondhalgh and Anamik Saha (2013) outline, '[c]ultural production in the modern world cannot be adequately understood without taking account of race and ethnicity, and their relation to oppression' (p. 180). In agreement with this perspective, and extending upon such a statement, I affirm the need for related research to investigate how issues regarding race and ethnicity-more specifically, anti-Blackness - intersect with those concerning gender, class, dis/ability, homophobia, xenophobia, transphobia, and other interdependent forms of systemic oppression. 
The nuanced experiences of Black people in Britain are often overlooked and/or reduced to (re)presentations emptied of substance as part of dominant discourse pertaining to media, the creative and cultural industries, inequality, and public life. Nevertheless, some of the experiences of Black people in Britain have been the focus of critical events and dialogue over the decades, including the following: a November 1988 conference report on Black People, Human Rights and The Media (Black Rights [UK] 1988), The Race and New Technology Conference 1985 (Morris 1986), Association of Black Film and Video workshops in the 1980s, as well as an International Women's Week event in 1986 at The Black-Art Gallery in London, titled 'And all of us are strong': Discussing Black Women's Art.

The Black Women and Media Conference (14-15 April) at The Factory in West London in 1984, which was attended by over 150 women, 'provided space for Black women and women of colour to talk about different aspects of the media in this country as well as a chance to share their skills' (Spare Rib 1984a, p. 18). Such an event exemplifies how for decades Black women have actively addressed issues concerning intersecting inequalities and the media in Britain. Second-wave feminist magazine, Spare Rib (1984a), describes the Black Women and Media Conference as having involved workshops to discuss topics such as (p. 18):

Black women's access to the media, the media's role in perpetuating racism and sexism, a Black women's media network, access to the media and sharing skills, training courses and control of images presented of Black women in the media, and how the feminist media/Black media could be made more accountable to Black women's needs and issues.

A workshop on 'Black Women and the Media' at the second National Black Women's Conference coordinated by OWAAD (29-30 March) in Tottenham, North London, in 1980, further indicates how Black women in Britain have been collectively organising around issues connected to their media experiences for many years.

More recently, co-founded by Paula Akpan and Nicole Crentsil in 2017, Black Girl Festival is a vibrant annual event that takes place in London and brings together Black women, girls and, non-binary people as part of a day of workshops, panel discussions and activities that focus on issues that are particular to their lives-including, but not limited to, matters to do with the arts, media, publishing, and the creative and 
cultural industries. In previous decades, conferences specifically focused on Black women's experiences and Black feminism in Britain included a two-day event from 19-20 May at University of London Union in 1984 (Spare Rib 1984b), attended by Black women from parts of Britain such as Bristol, Edinburgh, and Leicester. Writing about such events in the 1980s acknowledges specific isolation felt by Black women outside of London (Spare Rib 1984b) which serves as a reminder of the role of regionality in experiences of Black life in Britain, especially in parts where distinctly few Black people live.

In addition, as writer Marla Bishop (1987) wrote about in Spare Rib, Black women in Britain have engaged with the creative work of Black women in the US 'to redress the balance of the visibility of Black women on film' (p. 32). Such efforts in the 1980s included supporting the screening of a package of films by directors Ayoka Chenzira and Julie Dash which were shown at regional British cinemas including Chapter, Cardiff (April 2) and Filmhouse, Edinburgh (April 15-16). As is discussed in more detail in chapter four, when interviewing Black women in Britain about their media experiences, many who I spoke to enacted, what may be described as "discursive forays into "black America" (Nassy Brown 1998, p. 291) - commenting on how depictions of, and, discussions led by Black women in the US shaped their own media experiences and lives.

In the present-day context of Scotland, the work of individuals including writer, curator, artist, and organiser layla-roxanne hill who advocates for non-commodifiable collective liberation, foregrounds the creative and lived experiences of Black women who are most structurally oppressed due to the workings of anti-Black racism, sexism, classism, homophobia and xenophobia. hill's work includes many years of grassroots and collective activism, in addition to her co-organisation of events and activities in collaboration with the National Union of Journalists Scotland, and The Race Beat-a UK media network for people of colour (hill $2017,2019)$. There is no shortage of examples of consciousness-raising and collaboration between Black women in Britain (Bryan et al. 2018). However, there is limited scholarship regarding the role of digital media in this, and, to draw on the Black feminist words of writer and activist Audre Lorde (1988), as part of 'how we deal with each other across our own differences as Black women' (p. 39).

Although 'the mid-1950s is taken as the point when Black people began to settle in Britain in significant numbers' (Ngcobo 1987, p. viii), such a presence in Britain long predates the twentieth-century, including 
due to the impact of colonialism and the enslavement of Black people. After Windrush - which involved the mass migration of Black Caribbean people to Britain between the late 1940s and the start of the 1970s (Brinkhurst-Cuff 2018), the 1980s yielded a somewhat changing landscape of Black women's representation in Britain. Such changes included Labour party politician Diane Abbott becoming the first Black woman to be elected to the House of Commons in 1987 and who has continued to serve as a Member of Parliament (MP) for Hackney North and Stoke Newington since then.

Titled 'Black and Ethnic Minority Women', the March 1986 Issue (27) of the Greater London Council Women's Committee Bulletin provides a vivid snapshot of life for some Black women in Britain then. The Issue opens by highlighting that it is likely to be the last of the Bulletin's threeyear span (1983-1986), which commenced with an inaugural issue in celebration of what is referred to as the 'Anti-Racist Year'. The Bulletin was produced at a time when notions of solidarity between people from perceived 'minority ethnic groups', based on a shared anti-racist, anti-capitalist, and anti-imperialist political position-since then dubbed 'political blackness'-meant that the term 'Black' was not exclusively used in relation to Black people of African descent. Instead, 'Black' was also sometimes used in reference to those of Asian descent and other individuals identified as 'ethnic minorities' (Maylor 2009) —in ways that can diminish and deny distinct differences between people, including experiences and perpetuation of oppression (Jameela, forthcoming, 2020). As the Cruel Ironies Collective (2019, p. 187) state in reference to political blackness:

When Black people and non-Black people are homogenised into a single category based on sameness this can potentially serve to hide and/or deny anti-Blackness. The fantasy in which non-Black people of colour are unable to oppress Black people is upheld by ignoring the lived experience of Black people who have structurally experienced anti-Blackness from non-Black people of colour.

Formations of '[s]olidarity between different racialised women can never be taken for granted' (Emejulu and Sobande 2019, p. 6). Furthermore, as educator and writer Lola Okolosie accounts for in the forward of the republished version of The Heart of the Race: Black Women's Lives in Britain (Bryan et al. 2018), 'Thirty years on from its initial reception, 
'black' as a political identity under which empire's unaccounted-forchildren could unite has become hotly contested' (Okolosie 2018, p. xi), and rightly so. Thus, when reading the March 1986 Issue (27) of the Greater London Council Women's Committee Bulletin, I did so with an awareness of the racial politics in Britain at that time-the 1980s-and the need to carefully identify how the term 'Black' was used in all of the literature I came across and in reference to whom.

The March 1986 Issue (27) of the Bulletin documents the existence of the London New Technology Network's Women's Training Course Project Group, which was linked to work that addressed the information communication technology (ICT) experiences of 'Black and minority ethnic $(\mathrm{BME})^{1}$ women'-such as via the Minorities Information Technology Awareness Group (MITAG). As is evident when reading the Bulletin, power relations embedded in ICT, and critiques of how they impact different people, have been around for a long time before the rise of online content-sharing platforms and social media such as Twitter, Instagram, Facebook and YouTube. This is notable when reflecting on the creation of groups decades ago, such as The MITAG Women's Unit which was based in Camden and involved efforts to challenge the patriarchal and paternalistic way that ICT training was often delivered (Morris 1986).

In the 1980s there was already anxiety about the possibility that ICT could prove to be detrimental to the health and wellbeing of racialised people through an increasing sense of alienation. Shaped by what may be referred to as 'victim/agent dualisms' (Kanai 2019, p. 16), such concerns included the worry that women would be isolated due to the potential for new technology to make them 'passive objects with no control over the technology' (Morris 1986, p. 40). In Britain today there are similar worries, and, sometimes, indications of unwarranted moral panic surrounding the potential for digital technology to lead to social isolation. There are also continued assumptions that even once people have sustained access to and understandings of new technology, individuals from structurally oppressed social demographics-including Black people - are intrinsically incapable of using this technology in active and agentic ways. Such assumptions are often buttressed by systemically discriminatory perceptions of people's (in)abilities, which in some cases are based on classist, anti-Black, and xenophobic points of view, alongside the normativity of how whiteness is associated with technology, digital literacy, and so-called 'progress' and 'advancement' (Hobson 2008). 
Still, concerns articulated in the March 1986 Issue (27) of the Greater London Council Women's Committee Bulletin-penned when the 'computer age' (Spare Rib 1992, p. 58) was perceived as 'taking its toll' (ibid.) on people's health and wellbeing-are not misguided. Views also recorded in Spare Rib (1992) illustrate a point in history when many worries about the potentially hazardous impact of ICT on women's health predominantly focused on physical dimensions of this, such as headaches and effects on posture and reproductive biology. However, such perspectives were formed before the rise of online harassment and abuse which can impact both physical and mental health, and such points of view also predated the more widespread realisation of the agency that women can now exert online-albeit, in ways that are structurally restrictive.

Accordingly, chapter three features a discussion of how the contemporary digital experiences of Black women in Britain can benefit them in various ways, and, for some, involve 'do-it-together' (DIT) content creation and a sense of collectiveness which is a far cry from social alienation. There is also reflection on some of the many dangers that Black women in Britain deal with online. Before considering such issues, I reckon with the messy and ubiquitous politics of representation in society, while affirming that although representations are often far from being radical, revolutionary, or resistant in nature, representations and the processes that result in their production are always political.

\section{The Politics of Representation}

The expression 'representation matters' often prompts mixed responses and many questions concerning how representation is being defined, whose representation is being referred to, and, as has been extensively studied by sociologists, cultural theorists and political activists such as Stuart Hall, what the function of such representation is (Hall 1997; Hall et al. 2012). The media and communications scholarship of Sarah BanetWeiser (2018) explicates the persistence of a contemporary 'economy of visibility' (p. 2), within which representations-including those associated with popular feminism-are valued for their ability to increase the visibility of something or someone, as opposed to their capacity to contribute to substantial sustained action and social change. Attuned to digital culture and constant demand for attention and viral content 
online, Banet-Weiser's (2018) conceptualisation of an 'economy of visibility' (p. 2) captures 'a media landscape that is many things at once: a technological and economic context devoted to the accumulation of views, clicks, “likes", etcetera' (ibid.).

Banet-Weiser's (2018) insightful examination of the relationship between consumer culture, capital, media representations, marketing, popular feminism, and visibility elucidates the spectacle surrounding depictions of people and social movements in commercial campaigns and content. Returning to such work on an 'economy of visibility' (BanetWeiser 2018 , p. 2), in chapter three I consider how (re)presentations of Black people feature as part of the digital marketing content of creative and cultural industry organisations in Britain-objectifying and spectacularising Black people in ways that suit institutions' self-serving communications strategies.

In some cases, representations that appear in media and marketplace settings are inextricably linked to what sociologist Herman Gray (2004) refers to as being 'the Struggle for "Blackness", 'Black Cultural Politics and Commercial Culture' (Gray 2004, p. 1), as well as elements of viral and clickbait digital culture (Gray 2015). Gray's (2004) scholarship on race, television and Blackness includes observation that amid 'the contemporary politics of black popular culture, much critical attention has been given to identity and expressive culture' (p. 1), and such 'critical discourses and the popular attention they have generated play a strategic role in the maintenance of and challenge to various systems of domination' (ibid.).

The work of Africana studies scholar Marquita Marie Gammage (2016) also provides sharp analysis of issues regarding Black media depictions, by examining media portrayals of Black women and how they communicate ideas about Blackness to a watchful public. Furthermore, focusing on the context of Britain, the work of marketing communications scholar Deborah Gabriel (2016) illustrates how Black women have represented themselves in the blogosphere in ways that have enabled 'discursive activism to challenge stereotypical raced and gendered representation in the mainstream media' (p. 1622).

Media and political representation can play a useful part in collective, activist, resistant, and social justice-oriented work. More specifically, as I outline as part of prior analysis of 'memes, digital remix culture and (re)mediating British politics and public life' (Sobande 2019a, p. 153): 
Associated with a 'do it yourself' (DIY) or 'do it together' (DIT) ethos, digital remix culture involves the (re)production of various forms of media by people on the internet, including individuals without formal media training. Often by blending pop culture and political references, remixed digital content results in commentary that reflects different public conversations, contestations and concerns about the current state of politics and society.

Digital remix culture, including the widespread and strategic use of memes and GIFs, can arguably contribute to meaningful media, political critiques, and, perhaps, interventions, such as through 'the repurposing of photographs and the words of politicians and public figures, yielding acerbic statements that can be as critical and/or offensive as they are humorous' (Sobande 2019a, p. 153). However, the potential toxicity and superficiality of examples of media representation, both in digital spaces and elsewhere, include how entangled aspects of a represented person's identity (e.g. their race, gender, sexuality, and class) are assumed to be tethered to certain political perspectives-including, in some cases, socalled 'progressive' ones that are attributed to a wider social group that they are deemed to be part of.

As is explained in sociologist and African American studies scholar Ruha Benjamin's (2019) leading work on Race After Technology, '[e]conomic recognition is a ready but inadequate proxy for political representation and social power' (p. 19). Contrary to what is sometimes alluded to by the expression 'representation matters', an increase in the media representation of people from a systemically oppressed social demographic does not equate to, or, reflect, structural moves towards a more equitable society (Warner 2017). 'Representation matters' may be uttered as part of reductive claims that the mere presence of more Black women in media and political domains advances Black women's alleged inherent and shared political position-an assumed unified politics that is implied to equally prioritise all Black women's lives and struggles.

This is further illustrated by the necessary and in-depth research of social geographer Azeezat Johnson (2017) whose work affirms the importance of acknowledging and understanding nuanced differences between forms of structural oppression experienced by Black women. Johnson (2017) examines how the persistent entanglements of anti-Black racism, sexism, and Islamophobia specifically impact Black Muslim women in Britain. These observations of Johnson's (2017) are evident in the 
comments of Poppy-one of 26 Black women ${ }^{2}$ who I interviewed as part of research that informed this book.

Poppy is a Black Muslim woman and mother of young children who referred to herself as being between ' 37 and 40 years old'. She is based in Scotland where she has lived since moving there years ago from a city in West Africa. When I met with Poppy, she spoke in detail about her decision to turn down an opportunity to appear in a media project in Scotland about Black life there, despite her strong personal and professional interest in such issues:

I wasn't quite comfortable with the idea of featuring in a media project because of my accent, and thought my accent might put people off...I thought, they [Black people] are the silent minority, nobody knows them, why don't we celebrate them. I didn't know if I'd be accepted and I wear the hijab and I just thought... are they ready for a Muslim woman on the screen? She's Black, she's [laughs] she's got an accent, she's got a hijab on, she's this and that...

Poppy was the only woman I interviewed who explicitly discussed how the entanglements of anti-Blackness, sexism, misogyny, xenophobia, and Islamophobia impact Black Muslim women in Britain, and, as in Poppy's case, can deter and prevent some such women from pursuing media industry aspirations. Poppy's comments implicitly point to the futility of media industry 'diversity' initiatives which are marketed as enabling Black peoples' entry into careers in the industry, but which fail to identify institutional measures to support such individuals in the likely event that their hyper-visibility in the media leads to abuse from the publicincluding anti-Black, xenophobic, sexist, misogynistic, and Islamophobic abuse, which is also impacted by colourism.

Experiences of venomous anti-Black racism and Islamophobia that Poppy spoke to me about are a snapshot of numerous examples of how, contrary to the message of much public discourse, Scotland is far from being a so-called 'post-racial' society that is tolerant of all people (Folorunso 2019). Of the 14 Black women in Scotland who I interviewed, all spoke about anti-Black racism in that context-from their own painful experiences to those of their children, friends, and family. Poppy discussed how markers of her racial, religious, gender, and ethnic identity are interpreted in discriminatory ways that result in her being positioned 
as a hyper-visible Black African Muslim woman who is socially located outside of narrow notions of Scottish [white] identity.

Poppy acknowledged that Scotland has a creative industries landscape (Wells and Valencia 2017) but spoke about there being less media industry opportunities for Black women in Scotland than those that appear to be available in England-where there are more cities identified as creative and cultural hubs (Allen and Hollingworth 2013) and with larger populations of Black people. This observation should not be mistaken for suggesting that there is anywhere in Britain where Black women do not experience structural oppression and challenges in terms of their pursuit of media, creative, and cultural industry opportunitiesfar from it. Instead, Poppy's observation, which was echoed by the other Black women in Scotland who I spoke to, reflects how such challenges may be exacerbated by regional factors which link to the (un)availability of industry opportunities and the extent to which different Black women are (in)visible and hyper-visible.

When reflecting on the salient nature of her identity as a Black African Muslim woman in Scotland, and how she subsequently navigates media opportunities, Poppy alluded to forms of strategic (in)visibility and intentional opacity (Glissant 1997) which can play a part in how some Black women in Britain negotiate tensions between desire and demand for their representation, and the prospect of subsequent surveillance, harassment, abuse and danger that their visibility may prompt. The relevant concept of 'aesthetic-political space' (Scott cited in Scott et al. 2016, p. 5) encompasses how the aesthetic and ideological are intrinsically linked in ways resulting in visual expressions of political and personal meanings, including in the form of media imagery. As 'visual media are ever more the vehicle by which people make sense of their racialized and gendered world' (Joseph 2019, p. 27), learning about people's experiences of such media can aid understanding of co-constitutive issues concerning identity, inequality, and ideology.

Although magazines such as British Vogue, now under the direction of Edward Enninful, have started to feature more Black women on their pages and covers, in 2017 there were months when none of Britain's best-selling magazine covers featured a Black person (Hirsch 2018). The limited depiction of Black women in Britain in the media, as well as their treatment within the industry, continues to be a source of frustration for some (Olumide 2019). This is expressed in online articles including 'News Blackout - Why Aren't Black British Women Treated Fairly In 
the Media?' (hill 2017), 'Who Stole All the Black Women from Britain?' (Dabiri 2013), and 'Why black British drama is going online, not on TV' (Adewunmi 2012).

Those I interviewed spoke of their efforts to avoid specific media outlets which they identified as often communicating stereotypical ideas and images of Black women, which promote anti-Black and sexist ideologies that are connected to a 'white imaginary' and 'white mainstream media' bolstered by heteronormative and patriarchal positions. Such perspectives connect to the inimitable words of writer, editor, scholar, and so much more-Toni Morrison (2017, p. 37):

Far from our original expectations of increased intimacy and broader knowledge, routine media presentations deploy images and language that narrow our view of what humans look like (or ought to look like) and what in fact we are like.

As is unpacked in the following chapters, for some Black women in Britain, their rejection of various mainstream media channels forms part of wider and strategic attempts to create and source media depictions of, by, and benefitting, Black women-outside of the claustrophobic confines of mainstream mass-media in Britain (Sobande 2017; Sobande et al. 2019).

From tourism activity that is dependent on 'the association of blackness with servitude' (Wilkes 2016, p. 8), to brands that attempt to perform a proximity to Blackness (Crockett 2008), there is an extensive list of examples of how ideas about Blackness, images of Black people, and Black people themselves, are used as part of consumer culture (Sobande 2019b). At times, representations are nothing more than shallow, surface-level, and tokenistic in their makeup-devoid of any connection to substantial social change or political commitments and liberationist goals. Even so, from literary settings to the small screens of mobile devices, representations of Black women continue to be constructed, deconstructed, and reconstructed by them in meaningful ways that are worthy of acknowledging and understanding (Bobo 1995, 2001; Gabriel 2016; Melancon 2014).

Departing from the ambiguous, easily contorted, and, sometimes meaningless, notion that 'representation matters', my book is more firmly grounded in the belief that representation is political, regardless of any attempts to profess its neutrality and objectivity. Moreover, despite the frequent focus on media depictions and the image of people in publicfacing roles, I affirm that discussion and writing about the politics of 
representation must equally attend to who is present in media production activities, why they are, how they are treated, as well as how such concerns connect with material conditions and ideological infrastructures (Warner 2017).

\section{Conceptualising Black Women's Media REPRESENTATION AND EXPERIENCES}

Media depictions present people with 'the reimagined, reinvented version of the real' (hooks 2009, p. 1), and media's weighty influence in society includes its capacity to transmit political positions and reflect structural power relations. Media images and the meaning-making that they catalyse can appear to be a unifying communication force, while also mirroring social hierarchies. As has been raised by Black women and Black feminist writers, activists, creatives, cultural commentators, critics, and scholars, Black women have been (mis)represented and maligned in media, visual culture, and public life throughout history (Bryan et al. 2018). Their image and labour has also frequently been exploited in the service of capitalism and its patriarchal, racist, sexist, heteronormative, colonialist, and ableist underpinnings (Davis 1981).

Conversely, Black women around the world produce and share media content as part of resistant and activist work which challenges the structural conditions that diminish their quality of life, as well as the lives of others. Among examples of this is the use of hashtags (Jackson et al. 2017, 2020 ) and social media to raise awareness of the police brutality, violence, and oppression that is aimed at Black women (Omonira-Oyekanmi 2016)—including interlocking transphobia, cis-sexism, misogyny and anti-Black racism that Black trans* women face; all of which is commonly under-reported and misrepresented in mainstream mass-media in Britain (Alabanza 2018; Brinkhurst-Cuff 2019).

Media and marketplace environments are filled with symbols and scenarios spawned by racism and colonialism (Grier et al. 2019; Johnson et al. 2019; Sobande 2019b) which can contribute to people's perceptions of others, as well as their self-perceptions. Media depictions and the narratives that they are couched in can distinctly impact the lives of Black women, even as children 'who are often told from an early age that we have to be more aware of how others perceive us, how we appear in society is often more important than asserting our individuality' (Dawes 2012, p. 49). The groundbreaking work of information 
and communication studies scholar Safiya Umoja Noble (2018) highlights the oppressiveness of algorithms and the racist content yielded by online search engines. Such scholarship emphasises that, from childhood, Black women are often societally spectacularised and framed as hypersexualised, due to interlocking anti-Black racism, sexism, misogyny and other interconnected power dynamics (Noble 2018).

The work of both Noble and educational psychology and African American studies scholar Brendesha M. Tynes (2016) outlines how intersecting oppressions occur online and in relation to representations of Black women (Noble 2018). Relatedly, the preeminent Black feminist scholarship of sociologist Patricia Hill Collins (2000), which explicates a societal matrix of domination, is crucial to understanding how Black women are portrayed as part of 'controlling images' that are 'externally defined'. Hill Collins (2000) explains how instrumentalised stereotypes and associated images of Black women, created by other people, have been used for centuries as part of a matrix of dominant oppressive ideological efforts that contribute to their structural mistreatment.

The scholarship of Hill Collins (2000) stresses that controlling images of Black women contrast with those of white womanhood which are promulgated through 'the cult of true womanhood' (p. 72); positioning white women as racially unmarked women and Black women as being 'the Other'. Many controlling stereotypes have doggedly followed the depiction of Black women in media (Bailey 2020), including those that frame them as stoic, predatory, fetishised, and exoticised. Efforts to break stereotypes may be rooted in an aim to tackle oppressive structures and power relations, but as is outlined in the writing of cultural producer Tobi Kyeremateng (2019), obsessions with breaking stereotypes can involve pandering to 'the lens of whiteness'.

In 1992, Black feminist, scholar, and activist bell hooks asserted that there was a relative scarcity of writing by Black women which specifically focuses on their gaze and encounters as spectators. In addition to hooks' many years of work that foregrounds such issues in the US, Black feminist and women's studies scholar Jacqueline Bobo (2001) has vividly written about related matters-including Black women's creative, media, and cultural contributions, and formation of interpretive communities. Bobo (2001) writes about how Black women take part in the 'work of reclamation and redefinition' (p. 5) via their participation in and creation of media and cultural contexts, as active creators and spectators rather than mere passive consumers. Since the publication of Black Looks: Race and 
Representation by hooks (1992), Black Feminist Cultural Criticism by Bobo (2001), and Black Feminist Thought: Knowledge, Consciousness, and the Politics of Empowerment by Hill Collins (2000), scholarship by Black women and about their media and cultural experiences has expanded.

Regardless, in the context of media and cultural studies, and associated fields of research in Britain, such work remains relatively scant. Often when Black women's perspectives have appeared in such scholarly output, they have done so via the words of non-Black researchers, including those who do not tarry with how their own positionality and politics is implicated in their work and (mis)readings of Black women's lives. Some research in the field may be deemed part of what Nadine Chambers (2019) insightfully identifies as being 'the difficulty of how anti-Blackness can arrive disguised as social justice work and/or academic scholarship' (p. 31)—discussed in detail in Chambers' independent research on Black and Indigenous geographies.

Also, as is affirmed by sociologists Jennifer Patrice Sims and Chinelo L. Njaka (2019, p. 2), ' $[\mathrm{t}]$ he different linguist manners and rhetorical strategies used to ask about race within the US and UK, despite both having a dominant colourblind ideology, underscores how race is differentially constructed in the two nations'. Such explanations emphasise the need for work about the lives of Black women in Britain which considers the complexities of this specific context and the current political climate, alongside longstanding anti-Black structures that they are traversing. The following paragraphs discuss the experiences of Black women among different generations, including those that are part of a Black diaspora that 'came of age in a context of world-transforming dislocations at national, regional, and global levels' (Scott cited in Scott et al. 2016, p. 4).

\section{Representations of Black Women on Television}

The media landscape in Britain includes well established and mainstream television, print, radio and film outlets, as well as independent start-up production companies, digital-only media spaces and content created by people online. Although social media turned out to be the focus of a lot of my discussions with 24 of the 26 Black women who I interviewed-I found out that televised content had also played a central part in the lives 
of most of them at some stage, particularly media depictions of Black women that they came across as children.

When interviewed, Plantain Baby, who is in her twenties, is an artist, and is based in England, wistfully reflected on representations of Black women and girls in media that she encountered as a child in Britain:

I remember growing up and like, watching TV...there was a lot of like African American programmes, but of the Black British ones that were here...I remember Cleopatra. Cleopatra was, I feel like...the peak representation on TV to do with Black British girlhood...that's it! And that was a long time ago, there's no DVD, there's no reference, there's nothing...it just like, came and passed. I remember watching Cleopatra in the mornings 'cause they do reruns. I remember watching it on ITV when they did reruns... and they were three Black girls...I think they were from Birmingham...these three Black girls, and I thought they were so cool... and then okay, Naomi Campbell...this Black unapologetic supermodel, I remember...from Brixton...because it felt like...not like I knew her, but it was like...my cousins. Naomi Campbell, I can see her in my auntie, I can see her in my cousins... and it was something good to see all the time...it doesn't have to be an exact representation of you, but it was just seeing Blackness as much as possible, because we do exist, we are here...there were even some shows on BBC... there was this show on TV...Kerching!... and like the characters, the older sister and the sister's friends...that kind of TV show doesn't exist [now].

Plantain Baby also spoke fondly of the British subscription television channel, Trouble, which operated from 1997 to 2009 and featured many shows which included Black leading roles. Trouble was mentioned and remembered by 20 of the women who I interviewed-all of whom were under the age of 30 years old when we spoke, and who may be typified as 'millennials', by some. Among the women who spoke of Trouble fondly was Annie, who is in her late teens and is an undergraduate student based in England. Annie spoke about the notable part that Trouble played in her childhood media experiences:

When I was younger we didn't always have Sky...my mother didn't let us watch TV much, but they were showing Fresh Prince of Bel-Air...but when we did get Sky we saw that there were channels like Trouble, and Trouble did a good job, they called it 'urban' but there were quite a few shows where there were Black female leads, or even just Black females on the show, like My Wife and Kids, Girlfriends, Eve, there was Sister Sister, 
Moesha...but I was also aware, especially around aged 14 years old, that there are not really many Black females [on TV], especially in the UK. It's bad. It's really, really bad....and even in the shows like Kidulthood or whatever, the Black females will be shown by 'mixed-race' females, but by then I was already finding my shows online to watch...so yeah, I guess I did watch a lot [of television programmes with Black women in] them, but I guess I sought them out. I liked it [Trouble] and was always drawn to it because I just saw myself, and I guess with Trouble TV it was often comedy... and like, Friends was all the rage and I just didn't find it funny at all, but with the stuff on Trouble I could just relate to it, even stuff that they made light of, you had kind of seen it happen with your mum or cousins...could enjoy it more and I'd really get the jokes.

As Annie's comments touch on, due to colourism and co-dependent antiBlackness, often when Black women feature on-screen in Britain it tends to be images and the experiences of 'mixed-race' and light-skinned Black women that are foregrounded, and at the exclusion of dark-skinned Black women, or who are depicted in comparatively derogatory and degrading ways.

For many of the women who I spoke to who had grown up watching Trouble TV, it had represented a nostalgic 'golden era' of media depictions of Black women of different shades, yet, had still featured shows that contained colourist messages, plots, and casting and production decisions that targeted dark-skinned Black women in oppressive ways. Many of the shows that were available on Trouble were also based on heteronormative narratives concerning heterosexual romance, marriage, and idealised family life-resulting in the hyper-visibility of on-screen depictions of heterosexual Black women, in comparison to the lack of depictions of lesbian, bisexual, and queer Black women.

Other comments about the colourism that was apparent in shows on Trouble include the following words in reference to The Fresh Prince of Bel-Air, which were said by Nymeria who is an artist in her twenties in Scotland:

The real aunt Viv! The real aunt Viv...it's funny 'cause they could have just picked another dark-skinned Black woman [to play her once the original actor-Janet Hubert-was reportedly fired from the show], but they made the decision to make her lighter-skinned, but the woman who played real aunt Viv was amaaaaazing!...I realised when I was re-watching it how much she meant to me. 
When speaking about the specific significance of Trouble TV for some Black girls and women in Britain, Nymeria said:

...the funny thing is I talk about that stuff with my white friends [now] and they have no idea what I'm on about because they didn't consume that media...they didn't feel the need to... when I'm like 'do you remember My Wife and Kids?', they're like 'no', everyone remembers Fresh Prince of Bel-Air but hardly anybody was aware of the Black TV on Trouble and I was sooo glad that existed...I still think that Moesha was like my fave....all I remember was watching this and feeling a sense of 'I need to watch this'.

Some of the comments of another woman who I interviewed, named Rachel, who is in her twenties and is a recent graduate based in England, were very similar to Nymeria's remarks about the significant role of Trouble TV in the childhood of some Black women in Britain:

I was in my own little world of Rachel growing up...it was only when like, I came to uni and started talking to other people [about Trouble TV], and they were like, 'what are you talking about? I've never heard of that before'.

Trouble was a relatively short-lived television channel that has an especially strong sentimental value for Black women in Britain who had access to it, grew up as children watching Trouble TV shows, and eventually witnessed the channel's decline. While Trouble offered media depictions of Black women that were often absent from many mass-media contexts in Britain, within the roster of shows that it featured there was still a dearth of depictions of Black women in and from Britain. When considering how Trouble influenced the childhood media experiences of some Black women in Britain, it is important to recognise that many of the shows that aired on the channel and featured Black casts were North Americanand as a result, may be interpreted as being part of what anthropologist Jacqueline Nassy Brown refers to as 'discursive forays into "black America" (Nassy Brown 1998, p. 291) in Britain, and which can impact the identities of Black people ( $\mathrm{t}$ )here.

Not all women who I spoke to were of a similar age or had access to Trouble TV as children, including Amoke, who is in her forties, works in the public sector and is based in Scotland. Amoke identified many restrictive stereotypes that she feels television depictions of Black women in Britain promote. Amoke, who moved to Scotland from a city in West 
Africa about a decade ago, and said the move 'was meant to be temporary actually', discussed perceived 'improvements' to the media representation of Black women in Britain:

My thoughts? It's different from when I first came here [Scotland]. Actually, looking back to then, I didn't even look for them [representations of Black women], probably because subconsciously I didn't even expect to see them, but now I think there is more...in terms of visibility of them, not necessarily what they do...you see more Black and minority ethnic women on tele...one of them is Charlene White on the 6 o'clock news and maybe 10 o'clock news and I think that's just fantastic, and one in the morning, like GMTV as well...so there are more women I think. I still don't think...I don't have any statistics, but I don't think it's nearly enough to make some sort of impression on a younger person, but as somebody who has lived through when there was even nothing...I actually...I don't remember when I first came. I was never a big tele person, but initially I remember this woman in EastEnders. I think she is still there...I don't actually remember her name but she's been there a long time and her little family...it's not...not that she's a negative image... what she does, but...she doesn't stand out as someone you admire, so she's...yeah, she's just a 'problem family' and switching from relationship to relationship, but she's there...it's only now that they are actually looking at them and what they do.

Amoke made remarks that encompass how issues concerning generational, regional, and diasporic identity can impact the media expectations and experiences of Black women in Britain-such as their perceptions of the extent to which on-screen depictions of Black women have changed or 'improved', as Amoke put it. Although media depictions of Black women on Trouble played a central role in the childhood experiences of some Black women in Britain-including Plantain Baby, Nymeria, Rachel, and myself-, as is indicated by similarities and differences between the perspectives of the women who I interviewed, this is not the case for all.

Amoke was one of several mothers who I spoke to. Others, including Poppy, shared experiences that were reflective of how 'parental attempts to (re)mediate the Black identities of their children may involve them drawing on a global range of marketplace symbolic resources' (Sobande 2018 , p. 45) in an effort to defy mainstream media messages that promote 'ideological notions of inferior African "otherness"' (Bonsu 2009 , p. 1). The mothers who I interviewed made comments that are 
illustrative of Black 'parents' awareness of the scope for media representations to influence perceptions of their children, as well as their children's self-perceptions' (Sobande 2018, p. 43).

The experiences of Black people in Britain took a 'dramatic and definitive shape during the 1970s, leading in turn to an unprecedented period of Black-British creativity during the early to mid 1980s' (Chambers 2017 , p. xiii). In the twenty-first century, the creative, collective and consciousness-raising endeavours of Black people in Britain continue to flourish (Rae 2020), sometimes in ways mediated by digital communication and marketplace activity. Britain's contemporary media landscape is one within which Black women are carving out spaces and producing platforms and media outlets of their own.

When speaking to Ruby, who is in her twenties, is based in England and has experience of working in the media industry in Britain, she said the following:

.... lot of the time when we talk about imagery of Black women, it's always very American centric...I don't really know why that's the case, 'cause I think that British drama is quite forward thinking with sci-fi stuff and dystopias, comedy dramas...it's so strange that when I think of Black women on TV I think of Kerry Washington and Shonda Rhimes...we didn't really think that we had the platform to share our own voices, or we didn't see representations of ourselves...then if we do see them, a lot of the time they're 'mixed-race'...I don't see many Black women in British TV or film and when I do see them, they're just throw away characters. A friend of mine created a little report on Black women for a channel and it had like 20 something million views shared, and they said as soon as the idea was pitched, they knew it would pick up, because Black women share and create the most content about themselves...when we create content, and when I say 'we', I mean like...young media savvy Black women and women of colour, we create content for $u s$, by $u s$, which is great...but sometimes it feels like we're just regurgitating the same message to people who already think the same...your own circle.

The depiction of Black women in media in Britain has changed in some ways throughout history, including as a result of the rise of social media and digital communication platforms. However, there are striking elements of Black women's media experiences which seem to be steadfast. Among these is the scarcity of Black women's substantial leadership presence amid many media institutions and production processes-with Black 
people's involvement in British television as actors, writers and producers only slowly starting to increase with significance in the 1980s.

Furthermore, due to the intersections of anti-Black racism, sexism and other types of entwined structural oppression, when working in the media industry, and many other industries, Black women in Britain are likely to face difficulties associated with precarious work which 'refers to all forms of insecure, contingent, flexible work - from illegalized, casualized and temporary employment, to homeworking, piecework and freelancing' (Gill and Pratt 2008, p. 3). Consequently, even when able to enter media and cultural industry-related work environments, Black women in Britain commonly face insurmountable structural barriers connected to a lack of job security, insufficient pay, and an absence of organisational support-linked to intersecting oppressions.

Ruby emphasised the deficiency of television representations of Black women in Britain and commented on the fact that when Black women are represented it is in a very narrow and stereotypical way, including as part of content that feels as though it has been created for the viewing pleasure of people who in fact perpetuate the anti-Black types of oppression that Black people face. Many of those who I interviewed discussed their efforts to avoid certain media outlets which they feel distribute stereotypical images of Black women and uphold racist and sexist ideologies. This notion was part of why most of those who I spoke to dismiss the British Broadcasting Corporation (BBC), as well as various mainstream print magazines (Sobande et al. 2019) — particularly due to their awareness of the fact that ' $[\mathrm{m}]$ edia production and distribution systems remain primarily in the hands of white, elite men; and global information and capital flows still largely privilege their views, preoccupations, and economic goals' (Carter et al. 2014, p. 1). When I spoke to Ralph-Angel, who is in her thirties and is a photographer and graduate in Scotland, she emphasised this point (Sobande et al. 2019) when discussing why she 'just stopped watching the BBC and CNN and other stuff...all this mainstream white media'.

Ruby stressed the need for the media to depict Black women with more nuance and to account for their differences, including those shaped by colourism (Adegoke 2019; Amoah 2019; Gabriel 2007; Tate 2009, $2017 \mathrm{a}, \mathrm{b})$. The spirit of the words of singer-songwriter and consummate creative Solange Knowles when accepting her first Grammy Award in 2016 captures the sentiments of some of what was said by those who I interviewed: 
I think that visual art, in all aspects, are super important to me...creating strong visual representation of not only myself but, again, Black women, and getting to see us as avant-garde beings in a world that sometimes puts us in a box is really important to me.

Many Black women do not simply want to see more images and representation of Black women in the media. Instead, there is a demand for more of an expansive range of depictions, produced by Black women, for them, and as part of media and creativity that spans genres and generations.

\section{REgIONALITY AND RURALITY}

Studies of the relationship between Blackness and commercial culture have elucidated how the experiences of Black people in different parts of the world are remediated. In the case of sociologist Herman Gray's (2004) work, there is exploration of 'processes by which questions about the American racial order - and, within it, blackness-are constructed, reproduced, and challenged' (p. 1). While writing such as that of Gray's (2004) has illuminated some of the intricacies of how national politics and understandings of race and Blackness are pieced together within marketplace contexts, the workings of regional dynamics and the specifics of local settings have less commonly played a core part in research related to race, Blackness, media, and cultural spheres.

As hill (2019) succinctly puts it, 'representation of local news from smaller regions and towns beyond the central belt [in Scotland] or main cities still struggle to make it into new independent media'. This observation is also applicable to other parts of Britain where there is a greater amount of monetary, political, and societal focus on media content stemming from large cities, in comparison to material that originates in smaller areas. As is conveyed by the scholarship of Joy White (2019) on 'Growing Up in "The Ends": Identity, Place and Belonging in an Urban East London Neighbourhood', experiences of Black life in Britain are affected by the local surroundings that people find themselves living in, as well as the wider national setting that they are tied to.

Recognising how regional factors affect the lives of Black people, in videos for BBC The Social, writer Tomiwa Folorunso (2018a, b) discusses the experience of growing up Black and Scottish-affirming the need to acknowledge similarities and differences between the lives of Black 
women across various parts of Britain. When taking into consideration such perspectives, it is clear that meaningful efforts to learn about the media representation and experiences of Black women in Britain require an understanding of national and regional dynamics-beyond simply distinguishing between England, Scotland, Wales, and Northern Ireland. In addition, there is a need to scrutinise the prevalence of high-profile media from capital cities and the comparatively constrained visibility and funding available to media outlets, practitioners, creatives and freelancers in small towns and rural areas.

Patterns of migration and Britain's involvement in the transatlantic enslavement of Black people have resulted in the distinct presence of Black communities in cities including London, Liverpool, Cardiff, Manchester, Birmingham, and Glasgow (Bryan et al. 2018). However, Black women are not only based in large cities in Britain, as is reflected in the experiences of some of the women who I interviewed-including Lucy, who is in her twenties, is a creative performer and works in hospitality parttime in Scotland. Lucy voiced frustration concerning a lack of adequate media depictions of Black women who are from parts of Britain other than England. Lucy, who identifies as Scottish, spoke of 'the Scottish thing' being really important, and never getting to 'see anyone on TV who looked like us, and speaks like us'. When thinking about how significant it would have been to have had access to depictions of Black women in Scotland on TV when she was younger, Lucy paused before saying 'oh my god, it would have been the most amazing thing ever!'.

In the case of another woman who I interviewed, named Bobino, who is in her thirties, much of her life has been spent living in a rural part of England:

...somewhere with generated electricity, which means that the electricity goes off. There have been no neighbours, so it's fairly remote. And my mother's mother would make video recordings from films that were on television.

Bobino was one of two women I interviewed who spoke of living in a remote and rural area, where they were one of very few Black girls and women, if not, the only, Black girl or woman for miles. Bobino's experience of growing up without watching television and with limited access to electricity indicates how the different regional locations that Black women in Britain live in can influence their media experiences, as can other aspects 
of their home life and circumstances. Such a point is consistent with research regarding the digital experiences of Black and Latino youth in the US which highlights how regardless of 'living in a hyperconnected world where physical distance is often characterized as immaterial, geography - or more precisely, where people live - still matters' (Watkins et al. 2018 , p. 4). The experiences of Black women in Britain such as Bobino are a reminder of stark inequalities concerning Black women's access to the internet and televised media, including within countries where it is often mistakenly assumed that all people can simply go online or watch television at the touch of a button in their home.

\section{Concluding Thoughts}

The media experiences of Black women in Britain have changed over the decades but among what has remained consistent are struggles against their limited and derogatory depiction in 'controlling images' (Hill Collins 2000, p. 114) that are 'externally defined' (ibid.) by others. Constant challenges that such women face include contending with hostile and racist media institution environments when in pursuit of industry work, and the prospect of dealing with discriminatory backlash from the public when featuring on-screen and becoming hyper-visible in the media. As the words of Poppy indicate, oppressive responses to the depiction of different Black women in Britain in media can be the result of interlocking structural factors including, but not limited to, anti-Black racism, Islamophobia, xenophobia, sexism, and misogyny.

Since the days of events and collective work in the 1980s led by Black women in Britain concerning their media experiences and material conditions, increased availability and accessibility of digital devices and content-creation processes has resulted in new opportunities for Black women to relatively autonomously produce media, depict themselves, and generate discourse that counters dominant narratives. As is explored in detail in the next two chapters, attempts to counter how Black women in Britain have been systemically discriminated against within the media, creative and cultural industries, as well as society in general, include the digital efforts of Black women who collectively create together and build new avenues and activities to widely share their writing, work, and political organising. 


\section{Notes}

1. The term 'BME' which stands for Black and Minority Ethnic is one which rightly continues to be critiqued, including due to its use often involving a lack of specificity concerning racial and ethnic identities and experiences; especially at the expense of understandings of the lives of Black people of African descent and the particularities of anti-Blackness that they encounter. For this reason, the term 'BME' only features in this book as part of discussion of prior writing and research that makes use of it in connection to the lives of Black women.

2. The Black women who were interviewed include individuals who were born in Britain, as well as those who are migrants and refugees. At the time of the interviews, everyone resided in either Scotland or England. Those who were interviewed include individuals with different class backgrounds and socio-economic experiences, however, most had studied at college or university level. Among the Black women who were interviewed were individuals who are bisexual, heterosexual, lesbian and queer. Nobody specifically spoke about being cis, trans* or genderqueer, so the particularities of Black women's gender identities are not focused on in detail in this book but there is recognition of how Black trans* women and genderqueer individuals are most structurally oppressed and face specific forms of harassment, abuse, and violence that Black cis women do not.

\section{REFERENCES}

Adegoke, Yomi. (2019). 'Dark skinned women are now being celebrated, but don't blame us for scepticism.' Metro. Last modified 23 August, https://metro.co.uk/2019/08/23/dark-skinned-women-arenow-being-celebrated-but-dont-blame-us-for-scepticism-10619341. Accessed 5 November 2019.

Adewunmi, Bim. (2012). 'Why Black British drama is going online, not on TV.' The Guardian. Last modified 2 July, https://www.theguardian.com/world/ 2012/jul/02/black-british-tv-drama-online. Accessed 15 September 2016.

Akpan, Paula. (2019). 'How the stories of Black women in the UK are being reclaimed.' Refinery29. Last modified 10 October, https://www.refinery29. com/en-gb/black-women-history-uk. Accessed 15 October 2019.

Alabanza, Travis. (2018). 'Dear Naomi: We need to say her name.' gal-dem. Last modified 28 March, http://gal-dem.com/silence-failing-naomi-hersi. Accessed 5 April 2018.

Allen, Kim \& Hollingworth, Sumi. (2013). “"Sticky subjects” or "cosmopolitan creatives"? Social class, place and urban young people's aspirations for work in 
the knowledge economy.' Urban Studies 50(3): 499-517. https://journals. sagepub.com/doi/abs/10.1177/0042098012468901.

Amoah, Susuana. (2019). '\#NoShade: A critical analysis of digital influencer activism against shadeism in the beauty industry.' Academia.edu, https:// www.academia.edu/39881809/NoShade_A_Critical_Analysis_of_Digital_I nfluencer_Activism_Against_Shadeism_in_the_Beauty_Industry. Accessed 30 July 2019.

Bailey, Moya. (2020). 'A radical reckoning: A Black woman's racial revenge in Black Mirror's “Black Museum”.' Feminist Media Studies. https://doi.org/ $10.1080 / 14680777.2020 .1736120$.

Banet-Weiser, Sarah. (2018). Empowered: Popular Feminism and Popular Misogyny. Durham and London: Duke University Press.

Bassel, Leah \& Emejulu, Akwugo. (2017). Minority Women and Austerity: Survival and Resistance in France and Britain. Bristol: Policy Press.

Benjamin, Ruha. (2019). Race After Technology: Abolitionist Tools for the New Jim Code. Cambridge and Medford, MA: Polity Press.

Benson, Michaela \& Lewis, Chantelle. (2019). 'Brexit, British people of colour in the EU-27 and everyday racism in Britain and Europe.' Ethnic and Racial Studies 42(13): 2211-2228. https://www.tandfonline.com/doi/full/ $10.1080 / 01419870.2019 .1599134$.

Bentil, Jade. (Forthcoming, 2021). Rebel Citizen: A History of Black Women Living, Loving and Resisting. London: Penguin/Allen Lane.

Bishop, Marla. (1987). 'Black women and invisibility.' Spare Rib, Issue 1987 (177): 32 .

Black Rights (UK). (1988). Black People, Human Rights and The Media. London: Black Rights (UK) with the assistance of the Commission for Racial Equality.

Bobo, Jacqueline. (1995). Black Women as Cultural Readers. New York: Columbia University Press.

Bobo, Jacqueline. (ed.) (2001). Black Feminist Cultural Criticism. Malden, MA: Blackwell.

Bonsu, Samuel K. (2009). 'Colonial images in global times: Consumer interpretations of Africa and Africans in advertising.' Consumption Markets of Cultures 12(1): 1-25. https://www.tandfonline.com/doi/abs/10.1080/102 53860802560789.

Brinkhurst-Cuff, Charlie. (ed.) (2018). Mother Country: Real Stories of the Windrush Children. London: Headline.

Brinkhurst-Cuff, Charlie. (2019). 'Joy Morgan can be laid to rest, but more needs to be uncovered about her murder.' gal-dem. Last modified 11 October, http://gal-dem.com/joy-morgan-can-be-laid-to-rest-but-moreneeds-to-be-uncovered-about-her-murder. Accessed 15 October 2019. 
Bryan, Beverley, Dadzie, Stella \& Scafe, Suzanne. (1985). The Heart of the Race: Black Women's Lives in Britain. London: Virago.

Bryan, Beverley, Dadzie, Stella \& Scafe, Suzanne. (2018). The Heart of the Race: Black Women's Lives in Britain (2nd ed.). London: Verso.

Carter, Cynthia, Steiner, Linda \& McLaughlin, Lisa. (eds.) (2014). The Routledge Companion to Media and Gender. New York: Routledge.

Chambers, Eddie. (2017). Roots and Culture: Cultural Politics in the Making of Black Britain. London: I.B. Tauris.

Chambers, Nadine. (2019). 'Sometimes clocks turn back for us to move forward: Reflections on Black and Indigenous geographies.' Canada and Beyond: A Journal of Canadian Literary and Cultural Studies 8(2019): 22-39. http:// dx.doi.org/10.33776/candb.v8il.4566.

Cole, Marverine. (2018). "The "strong Black woman" stereotype is harming our mental health.' The Guardian. Last Modified 20 July, https://www. theguardian.com/commentisfree/2018/jul/20/strong-black-woman-stereo type-mental-health-depression-self-harm. Accessed 15 September 2018.

Crockett, David. (2008). 'Marketing blackness: How advertisers use race to sell products.' Journal of Consumer Culture 8(2): 245-268. https://journals.sag epub.com/doi/10.1177/1469540508090088.

Cruel Ironies Collective. (2019). 'Cruel ironies: The afterlife of Black womxn's intervention.' In To Exist Is to Resist: Black Feminism in Europe, edited by Akwugo Emejulu \& Francesca Sobande, pp. 181-194. London: Pluto Press.

Dabiri, Emma. (2013). 'Who stole all the Black women from Britain?' Media Diversified. Last modified 5 November, https://mediadiversified.org/2013/ 11/05/who-stole-all-the-black-women-from-britain. Accessed 15 May 2018.

Davis, Angela Y. (1981). Women, Race \& Class. New York: Random House.

Dawes, Laina. (2012). What Are You Doing Here? A Black Woman's Life and Liberation in Heavy Metal. Brooklyn, NY: Bazillion Points.

Emejulu, Akwugo. (2016). 'On the hideous whiteness of Brexit: "Let us be honest about our past and our present if we truly seek to dismantle white supremacy".' Verso. Last modified 28 June, https://www.versobooks.com/ blogs/2733-on-the-hideous-whiteness-of-brexit-let-us-be-honest-about-ourpast-and-our-present-if-we-truly-seek-to-dismantle-white-supremacy. Accessed 30 June 2016.

Emejulu, Akwugo \& Sobande, Francesca. (eds.) (2019). To Exist is to Resist: Black Feminism in Europe. London: Pluto Press.

European Women's Lobby (from the European Forum of Left Feminists). (1995). Confronting The Fortress: Black and Migrant Women in the European Union. European Parliament.

Folorunso, Tomiwa. (2018a). 'Growing up Black in Scotland [video].' BBC The Social. Last modified 15 October, https://www.youtube.com/watch? $\mathrm{reload}=$ 9\&v=WCzK2JkIodE. Accessed 9 June 2019. 
Folorunso, Tomiwa. (2018b). 'Learning about Black Scottish history! [video].' $B B C$ The Social. Last modified 29 October, https://www.youtube.com/ watch?v=EixjHZ9GaEk. Accessed 9 June 2019.

Folorunso, Tomiwa. (2019). 'Scotland is not this anti-racist utopia that we pretend it is.' The Herald. Last modified 28 October, https://www.heraldsco tland.com/news/17997473.scotland-not-anti-racist-utopia-pretend. Accessed 9 November 2019.

Gabriel, Deborah. (2007). Layers of Blackness: Colourism in the African Diaspora. London: Imani Media Ltd.

Gabriel, Deborah. (2016). 'Blogging while Black, British and female: A critical study on discursive activism.' Information, Communication \& Society 19(11): 1622-1635. https://doi.org/10.1080/1369118X.2016.1146784.

Gammage, Marquita Marie. (2016). Representations of Black Women in the Media: The Damnation of Black Womanhood. New York: Routledge.

Gill, Rosalind \& Pratt, Andy. (2008). 'In the social factory?: Immaterial labour, precariousness and cultural work.' Theory, Culture \& Society 25(7-8): 1-30. https://journals.sagepub.com/doi/10.1177/0263276408097794.

Gilroy, Paul. (1987). 'There Ain't No Black in the Union Jack': The Cultural Politics of Race and Nation. London: Unwin Hyman.

Glissant, Édouard. (1997). Poetics of Relation. Ann Arbor: University of Michigan Press.

Gray, Herman. (2004). Watching Race: Television and the Struggle for Blackness. Minneapolis: University of Minnesota Press.

Gray, Herman. (2015). 'The feel of life: Resonance, race, and representation.' International Journal of Communication 9: 1108-1119. https://ijoc.org/ index.php/ijoc/article/view/2238.

Grier, Sonya A., Thomas, Kevin D. \& Johnson, Guillaume D. (2019). 'Reimagining the marketplace: Addressing race in academic marketing research.' Consumption Markets \& Culture 22(1): 91-100. https://doi.org/10.1080/ 10253866.2017.1413800.

Hall, Stuart. (ed.) (1997). Representation: Cultural Representations and Signifying Practices. London: Sage in association with The Open University.

Hall, Stuart. (2001). 'Constituting an archive' Third Text 15(54): 89-92. https://doi.org/10.1080/09528820108576903.

Hall, Stuart, Evans, Jessica \& Nixon, Sean. (eds.) (2012). Representations: Cultural Representations and Signifying Practices (2nd ed.). London: Sage.

Hesmondhalgh, David \& Saha, Anamik. (2013). 'Race, ethnicity, and cultural production.' Popular Communication: The International Journal of Media and Culture 11(3): 179-195. https://doi.org/10.1080/15405702.2013. 810068.

hill, layla-roxanne. (2017). 'Blackout-Why aren't Black British women treated fairly in the media?' Last modified 30 March, http://nujscotland.org.uk/ 
2017/03/30/news-blackout-why-arent-black-british-women-treated-fairlyin-the-media. Accessed 30 June 2018.

hill, layla-roxanne. (2019). 'Know the media, be the media, change the media.' Bella Caledonia. Last modified 29 September, https://bellacaledonia.org. uk/2019/09/29/know-the-media-be-the-media-change-the-media. Accessed 3 October 2019.

Hill Collins, Patricia. (2000). Black Feminist Thought: Knowledge, Consciousness, and the Politics of Empowerment (2nd ed.). New York and London: Routledge.

Hill Collins, Patricia \& Bilge, Sirma. (2016). Intersectionality. Cambridge: Polity Press.

Hirsch, Afua. (2018). 'Glossies so white: The data that reveals the problem with British magazine covers.' The Guardian. Last modified 10 April, https://www.theguardian.com/media/2018/apr/10/glossy-mag azine-covers-too-white-models-black-ethnic-minority. Accessed 20 June 2018.

Hobson, Janell. (2008). 'Digital whiteness, primitive blackness: Racializing the "digital divide" in film and new media.' Feminist Media Studies 8(2): 111126. https://doi.org/10.1080/00220380801980467.

hooks, bell. (1992). Black Looks: Race and Representation. Boston: South End Press.

hooks, bell. (2009). Reel to Real: Race, Class and Sex at the Movies. New York: Routledge.

Jackson, Sarah J., Bailey, Moya \& Foucault Welles, Brooke. (2017). '\#GirlsLikeUs: Trans advocacy and community building online.' New Media \& Society 20(5): 1868-1888. https://doi.org/10.1177/146144481770 9276.

Jackson, Sarah J., Bailey, Moya \& Foucault Welles, Brooke. (2020). \#HashtagActivism: Networks of Race and Gender Justice. Cambridge, MA and London: MIT Press.

Jameela, Maryam. (Forthcoming, 2020). "'Violence, above all, is what maintains the breach": Racial categorisation and the flattening of difference.' In Black Film British Cinema II, edited by Clive Nwonka \& Anamik Saha. Cambridge: MIT Press.

Johnson, Azeezat. (2017). "“You're Othered here and you're Othered there": Centring the clothing practices of Black Muslim Women in Britain.' $\mathrm{PhD}$ Thesis, University of Sheffield. http://etheses.whiterose.ac.uk/id/eprint/ 18428.

Johnson, Azeezat, Joseph-Salisbury, Remi \& Kamunge, Beth. (eds.) (2018). The Fire Now: Anti-Racist Scholarship in Times of Explicit Racial Violence. London: Zed Books. 
Johnson, Guillaume D., Thomas, Kevin D., Harrison, Anthony K. \& Grier, Sonya A. (eds.) (2019). Race in the Marketplace: Crossing Critical Boundaries. Cham: Palgrave Macmillan.

Joseph, Ralina L. (2019). Postracial Resistance: Black Women, Media, and the Uses of Strategic Ambiguity. New York: New York University Press.

Kanai, Akane. (2019). Gender and Relatability in Digital Culture: Managing Affect, Intimacy and Value. Cham: Palgrave Macmillan.

Kyeremateng, Tobi. (2019). "Why the obsession with "breaking stereotypes" is harming Black people.' gal-dem. Last modified 25 September, http:// gal-dem.com/why-the-obsession-with-breaking-stereotypes-is-harming-blackpeople. Accessed 29 September 2019.

Larasi, Marai. (2019). 'Foreword.' In This Is Us: Black British Women and Girls, curated by Kafayat Okanlawon, pp. 5-9. London: Break the Habit Press.

Lewis, Gail. (1993). 'Black Women's Employment and the British Economy.' In Inside Babylon: The Caribbean Diaspora in Britain, edited by Winston James \& Clive Harris, pp. 73-96. London: Verso.

Lewis, Gail. (2000). 'Race', Gender, Social Welfare: Encounters in a Postcolonial Society. Cambridge: Polity Press.

Lewis, Gail \& Hemmings, Clare. (2019). "Where might we go if we dare": Moving beyond the "thick, suffocating fog of whiteness" in feminism.' Feminist Theory 20(4): 405-421. https://doi.org/10.1177/146470011987 1220.

Linton, Samara \& Walcott, Rianna. (eds.) (2018). The Colour of Madness: Exploring BAME Mental Health in the UK. Edinburgh: Stirling Publishing.

Lorde, Audre. (1988). A Burst of Light. New York: Firebrand Books.

Maylor, Uvanney. (2009). "What is the meaning of "Black"? Researching "Black" respondents.' Ethnic and Racial Studies 32(2): 369-387. https://www.tan dfonline.com/doi/abs/10.1080/01419870802196773.

Media Diversified. (ed.) (2016). From the Lines of Dissent. London: Out-Spoken Press.

Melancon, Trimiko. (2014). Unbought and Unbossed: Transgressive Black Women, Sexuality, and Representation. Philadelphia: Temple University Press.

Morris, Valerie. (1986). 'MITAG: Minorities Information Technology Awareness Group'. In March 1986 Issue (27) of the Greater London Council Women's Committee Bulletin, pp. 39-40.

Morrison, Toni. (2017). The Origin of Others. Cambridge, MA and London: Harvard University Press.

Nassy Brown, Jacqueline. (1998). 'Black Liverpool, Black America, and the gendering of diasporic space.' Cultural Anthropology 13(3): 291-325. https://doi.org/10.1525/can.1998.13.3.291.

Ngcobo, Lauretta. (ed.) (1987). Let It Be Told: Essays by Black Women in Britain. London: Pluto Press. 
Noble, Safiya Umoja. (2018). Algorithms of Oppression: How Search Engines Reinforce Racism. New York: New York University Press.

Noble, Safiya Umoja \& Tynes, Brendesha M. (eds.) (2016). The Intersectional Internet: Race, Sex, Class, and Culture Online. New York: Peter Lang.

Obasi, Chijioke. (2019). 'Africanist Sista-hood in Britain: Creating our own pathways.' In To Exist Is to Resist: Black Feminism in Europe, edited by Akwugo Emejulu \& Francesca Sobande, pp. 229-242. London: Pluto Press.

Okolosie, Lola. (2018). 'Preface.' In The Heart of the Race: The Lives of Black Women in Britain (2nd ed.), written by Bryan, Beverley, Dadzie, Stella \& Scafe, Suzanne. London: Verso.

Olumide, Eunice. (2019). 'I will not stop talking about the racism I face even if it means I lose my job.' Metro. Last modified 14 May, https://metro.co.uk/2019/05/14/i-will-not-stop-talking-aboutthe-racism-i-face-even-if-it-means-i-lose-my-job-9467895. Accessed 2 June 2019.

Omonira-Oyekanmi, Rebecca. (2010). 'The injustice of indefinite detention.' The Guardian. Last modified 5 October, https://www.theguardian.com/ commentisfree/libertycentral/2010/oct/05/british-immigration-removalcentres-injustice. Accessed 8 October 2019.

Omonira-Oyekanmi, Rebecca. (2016). 'Remembering Sarah Reed.' Open Democracy. Last Modified 13 February, https://www.opendemocracy.net/en/shinea-light/remembering-sarah-reed. Accessed 19 February 2019.

Otele, Olivette. (2017). 'History of slavery, sites of memory, and identity politics in contemporary Britain.' In A Stain on Our Past: Slavery and Memory, edited by Abdoulaye Gueye \& Johann Michel, pp. 189-210. Trenton: Africa World Press.

Otele, Olivette. (2019). 'We need to talk about slavery's impact on all of us.' The Guardian. Last modified 9 November, https://www.theguardian. com/commentisfree/2019/nov/09/slavery-impact-trauma-history. Accessed 18 November 2019.

Owusu, Melz. (2018). 'Decolonising the academy: A movement without borders.' Medium. Last modified 12 November, https://medium.com/ @ melz.artist/decolonising-the-academy-a-movement-without-borders-7a25c0 7ldb6e. Accessed 4 January 2019.

Palmer, Lisa Amanda. (2011). 'The politics of loving blackness in the UK.' PhD Thesis. University of Birmingham. https://etheses.bham.ac.uk/id/epr int/1508/. Accessed 7 January 2018.

Perry, Kennetta Hammond. (2016). London is the Place for Me: Black Britons, Citizenship, and the Politics of Race. New York: Oxford University Press. 
Rae, Mandla. (2020). 'Creative conversations: Black women artists making and doing-Institute for Black Atlantic Research, Preston.' Corridor8. Last modified 29 February, https://corridor8.co.uk/article/black-women-artists-mak ing-and-doing. Accessed 29 February 2020.

Scott, David. (2016). Cited in Scott, David, James, Erica Moiah \& Cunningham, Nijah. Caribbean Queer Visualities, pp. 3-5. Small Axe.

Sharpe, Christina. (2016). In the Wake: On Blackness and Being. Durham and London: Duke University Press.

Sims, Jennifer Patrice \& Njaka, Chinelo L. (2019). Mixed-Race in the US and UK: Comparing the Past, Present, and Future. Bingley: Emerald.

Sobande, Francesca. (2017). 'Watching me watching you: Black women in Britain on YouTube.' European Journal of Cultural Studies 20(6): 655-671. https:// doi.org/10.1177/1367549417733001.

Sobande, Francesca. (2018). 'Managing media as parental race-work: (Re)mediating children's Black identities.' In Consumer Culture Theory: Research in Consumer Behavior, Vol. 19, edited by Samantha N. N. Cross, Cecilia Ruvalcaba, Alladi Venkatesh \& Russell W. Belk, pp. 37-53. Bingley: Emerald.

Sobande, Francesca. (2019a). 'Memes, digital remix culture and (re)mediating British politics and public life.' IPPR Progressive Review 26(2): 151-160. https://onlinelibrary.wiley.com/doi/abs/10.1111/newe.12155.

Sobande, Francesca. (2019b). "Woke-washing: "Intersectional" femvertising and branding "woke" bravery.' European Journal of Marketing, Vol. Ahead-ofprint No. ahead-of-print. https://doi.org/10.1108/EJM-02-2019-0134.

Sobande, Francesca, Fearfull, Anne \& Brownlie, Douglas. (2019). 'Resisting media marginalisation: Black women's digital content and collectivity.' Consumption Markets \& Culture. doi.org/https://doi.org/10.1080/102 53866.2019.1571491.

Spare Rib. (1984a). 'Black women \& media conference.' Spare Rib, Issue 1984(143): 18.

Spare Rib. (1984b). 'We're here...Black women meet.' Spare Rib, Issue 1984(144): 21.

Spare Rib. (1992). 'Computer hazards.' Spare Rib, Issue 1992(234): 58.

Sulter, Maud. (1985). As a Blackwoman. London: Akira.

Sulter, Maud. (1986). 'Surveying the scene: Writings by women of African and Asian descent.' In March 1986 Issue (27) of the Greater London Council Women's Committee Bulletin, pp. 28-29.

Tate, Shirley Anne. (2009). Black Beauty: Aesthetics, Stylization, Politics. Farnham: Ashgate Publishing.

Tate, Shirley Anne. (2017a). The Governmentality of Black Beauty Shame: Discourse, Iconicity and Resistance. Basingstoke: Palgrave Macmillan. 
Tate, Shirley Anne. (2017b). 'Skin: Post-feminist bleaching culture and the political vulnerability of blackness.' In Aesthetic Labour: Rethinking Beauty Politics in Neoliberalism, edited by Ana Sofia Elias, Rosalind Gill \& Christina Scharff, pp. 199-213. Basingstoke: Palgrave Macmillan.

The Brixton Black Women's Group and the Organisation for Women of African and Asian Descent. (2017). Black Women Organising. London: Past Tense.

The Greater London Council Women's Committee. (1986). 'Black and Ethnic Minority Women.' The Greater London Council Women's Committee Bulletin (March): 27.

Twine, France Winddance. (2004). 'A white side of Black Britain: The concept of racial literacy.' Ethnic and Racial Studies 27(6): 878-907. https://www. tandfonline.com/doi/abs/10.1080/0141987042000268512.

Twine, France Winddance. (2010). A White Side of Black Britain: Interracial Intimacy and Racial Literacy. Durham and London: Duke University Press.

Walcott, Rianna. (2020). 'How the mental health system fails Black people.' Wellcome Collection. Last modified 28 January, https://wellcomecollection. org/articles/XhiLihAAACYAR42P. Accessed 29 January 2020.

Warner, Kristen J. (2017). 'In the time of plastic representation.' Film Quarterly Winter 2017, 71(2). Last modified 4 December, https://filmquarterly.org/ 2017/12/04/in-the-time-of-plastic-representation. Accessed 20 March 2020.

Watkins, S. Craig, Lombana-Bermudez, Andres, Cho, Alexander, Vickery, Jacqueline Ryan, Shaw, Vivian \& Weinzimmer, Lauren. (2018). The Digital Edge: How Black and Latino Youth Navigate Digital Inequality. New York: New York University Press.

Wells, Jaleesa Renee \& Valencia, Marta Bernal. (2017). 'Mapping the landscape of creative industries research in Scotland [software].' Edinburgh: Creative Scotland.

White, Joy. (2019). 'Growing up in "The Ends": Identity, place and belonging in an urban East London neighbourhood.' In Identities, Youth and Belonging: International Perspectives, edited by Sadia Habib and Michael R.M. Ward, pp. 17-33. Cham: Palgrave Macmillan.

Wilkes, Karen. (2016). Whiteness, Weddings, and Tourism in the Caribbean: Paradise for Sale. Basingstoke: Palgrave Macmillan.

Wilson, Melba. (1982). 'Black women writers.' Spare Rib, Issue 1982(119): 3132.

Young, Lola. (2000). 'What is Black British feminism?' Women: A Cultural Review 11(1-2): 45-60. https://doi.org/10.1080/09574040050051415. 
Open Access This chapter is licensed under the terms of the Creative Commons Attribution 4.0 International License (http://creativecommons.org/licenses/ by $/ 4.0 /$ ), which permits use, sharing, adaptation, distribution and reproduction in any medium or format, as long as you give appropriate credit to the original author(s) and the source, provide a link to the Creative Commons license and indicate if changes were made.

The images or other third party material in this chapter are included in the chapter's Creative Commons license, unless indicated otherwise in a credit line to the material. If material is not included in the chapter's Creative Commons license and your intended use is not permitted by statutory regulation or exceeds the permitted use, you will need to obtain permission directly from the copyright holder.

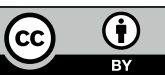

